\title{
Corporate Social Responsibility and Sustainability in Scandinavia: An Overview
}

\author{
Robert Strand • R. Edward Freeman • \\ Kai Hockerts
}

Published online: 28 May 2014

(C) Springer Science+Business Media Dordrecht 2014

\begin{abstract}
Scandinavia is routinely cited as a global leader in corporate social responsibility (CSR) and sustainability. In this article, we explore the foundation for this claim while also exploring potential contributing factors. We consider the deep-seated traditions of stakeholder engagement across Scandinavia including the claim that the recent concept of "creating shared value" has Scandinavian origins, institutional and cultural factors that encourage strong CSR and sustainability performances, and the recent phenomenon of movement from implicit to explicit CSR in a Scandinavian context and what this may entail. In sum, we depict the state of the art in CSR and sustainability in Scandinavia. We intend for this to serve as a basis to help establish a globally recognized research paradigm dedicated to considering CSR and sustainability in a Scandinavian context.
\end{abstract}

Keywords Scandinavia - CSR - Sustainability · Scandinavian cooperative advantage $\cdot$ Creating shared value

This article also represents the introductory article to the special issue "Scandinavian Approach to Corporate Social Responsibility \& Sustainability" with the Journal of Business Ethics.

R. Strand $(\square) \cdot$ K. Hockerts

Copenhagen Business School, Copenhagen, Denmark

e-mail: rs.ikl@cbs.dk

R. E. Freeman

Darden School of Business, University of Virginia,

Charlottesville, VA, USA

\section{Introduction}

Few can contest Scandinavia's place at the forefront of the corporate responsibility movement.

-Ethical Corporation (McCallin and Webb 2004)

The Nordics dominate indices of competitiveness as well as of well-being.

- The Economist (2013)

Scandinavia is routinely cited as a global leader in corporate social responsibility (CSR) and sustainability. Thus, perhaps not surprisingly, global attention to the CSR and sustainability activities from Scandinavia appears to be on the rise. In this article, we explore these claims that Scandinavian countries and Scandinavian companies are leaders in CSR and sustainability and consider potential contributing factors. We intend for this article to serve as a summary of the state of the art in the Scandinavian CSR and sustainability and to encourage the establishment of a research paradigm dedicated to exploring CSR and sustainability in a Scandinavian context.

This article also represents the introductory article to the special issue "Scandinavian Approach to Corporate Social Responsibility \& Sustainability" with the Journal of Business Ethics. Therefore, we highlight contributions made by each of the six selected articles:

- "From Implicit to Explicit CSR in a Scandinavian Context: The Cases of HÅG and Hydro," by Siri Granum Carson, Øivind Hagen, and S. Prakash Sethi

- "Governmentalities of CSR: Danish Government Policy as a Reflection of Political Difference," by Steen Vallentin

- "Reputation, Responsibility, and Stakeholder Support in Scandinavian Firms: A Comparative Analysis," by Deborah Vidaver-Cohen and Peggy Simicic Brønn 
- "Scandinavian Cooperative Advantage: The Theory and Practice of Stakeholder Engagement in Scandinavia," by Strand and Freeman

- "Scandinavian Stakeholder Thinking: Seminal Offerings from the Late Juha Nasi," by Juha Nasi ${ }^{1}$

- "Ye Olde CSR: Historic Roots of Corporate Social Responsibility in Norway," by Øyvind Ihlen and Heidi von Weltzien Hoivik

\section{CSR and Sustainability: What Are They?}

CSR and sustainability are discussed by some as near synonyms and by others as completely distinct concepts. In the latter scenario, CSR is oftentimes considered to be focused on social issues and sustainability on environmental issues (Carroll 1999; Dahlsrud 2008; Dyllick and Hockerts 2002; Schwartz and Carroll 2008). In its 2008 special issue on CSR, The Economist in effect endorsed the former approach when it invoked the phrase "corporate responsibility - or sustainability or whatever" when describing efforts on the part of corporations to consider business in society issues (2008, pp. 13). The "whatever" of this statement is indicative of the inherently imprecise nature and oftentimes interchangeable use of the expressions corporate (social) responsibility, sustainability, and a host of others. Moreover, shifts in use between expressions can be observed over time, where, for example, the expression sustainability appears to be gaining favor over CSR. This is likely due, at least in part, to managerial demand for more formally rational language. The language of sustainability is more formally rational than the language of CSR, which is more normative. This makes the language of sustainability more "CFO friendly" than CSR (Strand 2013a, 2014a).

Throughout this article, we utilize the expressions CSR and sustainability as "umbrella constructs" in the sense of Hirsch and Levin's (1999, pp. 200) description of an umbrella construct as "a broad concept or idea used loosely to encompass and account for a broad set of diverse phenomena" (Gond and Crane, 2010, pp. 680-681).

Given this approach, we could well include expressions like corporate citizenship (Carroll 1998; Matten and Crane 2005), business ethics (Bowie 1999; Beauchamp et al. 2009;

\footnotetext{
1 This article comprises two chapters written by Juha Nasi in the 1995 book Understanding Stakeholder Thinking (ISBN951-96013-68) published by LSR of Helsinki, Finland. This book had very limited distribution; hence, these chapters risked extinction. We offer our sincere gratitude to LSR for granting this reprint to keep alive these important offerings of the late Juha Nasi. When this article was first published online, the authorship on the title page was incorrectly given as Strand. As was corrected in an erratum, Juha Nasi is the rightful author of these contributions, and Strand serves as the correspondent.
}

Crane and Matten 2007, stakeholder engagement (Freeman, 1984; Freeman et al. 2010; Rhenman 1968), stewardship (Davis et al. 1997), triple bottom line (Elkington 1999), and creating shared value (Porter and Kramer 2011) in our discussions. These expressions are examples of the catchall "whatever" label per The Economist. In this article, stakeholder engagement in particular will be highlighted given that stakeholder engagement-and the expression stakeholder - has a long tradition in Scandinavia (Rhenman 1964, 1968). Strand and Freeman in this issue demonstrate that the first appearance of the word stakeholder in the published management literature originated in Scandinavia in the 1960s; furthermore, they contend that contributions to stakeholder theory originating from Scandinavia serve as a basis for the more recent concept of creating shared value, promoted by strategic-management gurus Michael Porter and Mark Kramer (2011). Given the worldwide attention to the concept of shared value, we more thoroughly explore this claim of Scandinavian origins.

There is no shortage of definitions for the expressions CSR and sustainability. Because we are treating these expressions as umbrella constructs, we do not strive for precision in definitions but rather offer the following commonly used definitions as a starting point for deliberations. Over the span of a decade, the European Commission has provided two definitions that represent what could be argued to have achieved the status of most widely utilized definitions of CSR. ${ }^{2}$ In 2001, the commission defined CSR as "a concept whereby companies integrate social and environmental concerns in their business operations and in their interaction with their stakeholders on a voluntary basis." A decade later, the commission updated its definition of CSR as "the responsibility of enterprises for their impacts on society." The expression sustainability (from the Latin $s u$ stinere, where tenere is "to hold" and sus is "up") is most commonly described as "development that meets the needs of the present without compromising the ability of future generations to meet their own needs," drawing from the definition of sustainable development as given by the UN's Brundtland Commission in 1987. Of potential relevance to these Scandinavian-focused discussions is that the commission's name refers to former Norwegian prime minister Gro Harlem Brundtland and the associated report within which this definition exists is commonly referred to as the Brundtland Report.

\footnotetext{
$\overline{2}$ For a more comprehensive list of CSR definitions and associated analysis regarding commonalities and differences across them, see Dahslrud (2008). Recently, Guthey and Morsing (2013) provide a definition that we feel is useful when considering meanings of CSR and sustainability: "CSR is best understood not as a clear or consistent agenda, but rather as a forum for sensemaking, diversity of opinion, and debate over the conflicting social norms and expectations attached to corporate activity."
} 


\section{Scandinavia: What Is It?}

Arriving at a clear-cut definition of Scandinavia is not so straightforward. Historically speaking, Scandinavia was usually meant to refer to the countries of Denmark, Norway, and Sweden (Bondeson 2003; Nordstrom 2000). The Danish author Hans Christian Andersen purportedly wrote the poem "I Am a Scandinavian" in 1839, after a visit to Sweden, to describe the connectedness he felt between the Danes, Swedes, and Norwegians (see Strand and Freeman in this issue). More recently, Finland is often included by many as part of Scandinavia; the expressions Scandinavian and Nordic are used almost interchangeably by a growing number of people (Bondeson 2003, p. 3; see also Derry 1979). Not all agree with this broadening. Within Denmark, Norway, and Sweden, one is more likely to encounter a definition of Scandinavia consistent with the traditional definition, whereas elsewhere, including within Finland, one may be more likely to find the broadening sense embraced. ${ }^{3}$

The word Scandinavia refers to the Scandinavian Peninsula, and thus the expression has geographical roots. But further exploration reveals that the peninsula earned its name from the cultural-linguistic concept of Scandinavia (Østergård 1997). Hence the words Scandinavia and Scandinavian typify both geography and cultural connections between the peoples of Denmark, Norway, and Sweden, who share similar histories and languages. The word Nordic refers to "north" and similarly can be used as a geographical construct or a cultural construct (or a combination of the two). In the present day, the expression Nordic has assumed a formal meaning through the Council of Nordic Minsters in reference to the formalized cooperation between governments of Denmark, Norway, Sweden, Finland, Iceland, Greenland, and the Faroe Islands.

Some authors of articles included in this special issue raise question regarding the degree to which it is helpful to consider Scandinavia as a unit of analysis (e.g., VidaverCohen and Peggy Simicic Brønn; Vallentin). Some of these deliberations are fueled by the title for this special issue, "The Scandinavian Approach to Corporate Social Responsibility and Sustainability." We were rightfully challenged by these authors regarding our implied assertion of a monolithic Scandinavian approach.

That said, we maintain that Scandinavia represents a worthy unit for consideration, provided one does not assume complete homogeneity within Scandinavia and a

\footnotetext{
${ }^{3}$ One could readily argue that generally speaking and specifically with respect to CSR and sustainability, Scandinavia and Scandinavians enjoy a mostly positive image throughout the world. Therefore, it may not be surprising that discussions can turn contentious around claims that a country or population is or is not part of the Scandinavian club.
}

singular Scandinavian approach. Castles (1978/2009, pp. xii-xiii) contends that there is room for both sorts of scholarship within the Scandinavian field: those who seek to highlight differences within Scandinavia ("insiders," as Castles refers to them as they are often Scandinavian nationals) and those who seek to contrast Scandinavia with the rest of the world ("outsiders"). We agree and, therefore, adopt a line similar to that of Morsing et al., who acknowledge differences while highlighting commonalities with their statement "although differences exist among the three countries ...in comparison with people from other European, U.S., African, or Asian countries, the Scandinavians appear to be rather similar. Their shared cultural, political, and societal background has given rise to the description of the particular 'Scandinavian management", (2007, pp. 88-89). ${ }^{4}$

Thus, one may be drawn to firm definitions of Scandinavia as a defined collection of countries, while others may be drawn to the concept of Scandinavia as having more to do with an identity-being Scandinavian - that could arguably transcend geographical boundaries. We do not attempt to resolve the debate and do not see much value in attempting to do so. While we will predominantly use the expression Scandinavia throughout and typically focus on Denmark, Norway, and Sweden, the expression Nordic will also be invoked.

\section{Scandinavian CSR and Sustainability Performances}

Scandinavian countries and Scandinavia-based companies perform disproportionately well in CSR and sustainability performance measurements. This includes the Dow Jones Sustainability Index (DJSI) and the Global 100 Index. As questions continue to mount about whether traditional economic measurements help or harm societal well being (Stiglitz et al. 2009), the CSR and sustainability performance measurements will likely realize increased attention.

Before we review a variety of CSR and sustainability performance measurements, it is important to acknowledge that efforts to measure CSR and sustainability performances are not without critics (Porter and Kramer 2006; Chatterji and Levine 2006; Chatterji et al. 2009). While we do not contend that measurements like the DJSI and Global 100 are without flaws, we propose that when these measurements (and their differing underlying methodological approaches) are gathered and considered as a collection, they can serve as useful performance indicator.

We begin with country-level performance indicators and then move to company-level indicators like the

\footnotetext{
${ }^{4}$ See also Grennes (2003).
} 
Table 1 Triple-bottom-line performance by country cluster

\begin{tabular}{llll}
\hline Country cluster & Economic & Environment & Societal \\
\hline Nordic & High & High & High \\
Anglo Saxon (incl. U.S.) & High & Low & Middle \\
Continental Europe & Middle & Middle & Middle \\
Mediterranean Europe & Low & Low & Low \\
Confucian & Middle & Low & Low
\end{tabular}

Adapted from "Toward Sustainable Sustainability Learning: Lessons from a US MBA Study Abroad Program in Scandinavia," by R. Strand, 2011, Journal of Strategic Innovation and Sustainability 7(2), $41-63$. High $=1$ to 1.9 , middle $=2.0$ to 3.5 , and low $=3.6$ or more

aforementioned DJSI and Global 100. We first highlight the study by Strand (2011) demonstrating country-level (and ultimately clusters of country-level) triple-bottom-line performances. In it, a suite of commonly used countrylevel indicators for economic performances (e.g., gross national income per capita and the Global Competitiveness Index), environmental performances (e.g., the Environmental Performance Index), and societal performances (e.g., the UN Human Development Index) were collected during 2005-2006 and consolidated by each of the triplebottom-line groupings: economic, environmental, and social. The country-level data were rolled up by commonly used country clusters (Castles 1993; Gupta and Hanges 2004)—like Nordic and Anglo Saxon ${ }^{5}$ - through which a high-level global comparison is provided, as shown in Table 1.

Care should be taken when interpreting datasets like this to include considerations that such datasets are often generated by "Western" criteria, and hence the outcomes likely bias Western countries. That said, within the Western groupings of countries, the Nordic region performs best and thus merits attention.

A number of similar findings have since been published. The World Economic Forum (2013) publishes the Sustainability-Adjusted Global Competitiveness Index (GCI), by which it aims "to assess the set of institutions, policies and factors that make a nation remain productive over the longer term while ensuring social and environmental sustainability." Of the 121 countries included in its 2013-2014 edition, the Top 10 is littered with Scandinavian and Nordic countries with Finland at number 2; Norway, number 5; Sweden, number 6; and Denmark, number 9 .

In another sustainability-minded ranking, the strategicmanagement guru Michael Porter threw his hat into the ring with his involvement in the Social Progress Index

\footnotetext{
5 The United States is dominant member of the "Anglo Saxon" cluster. In this study, Nordic refers to Denmark, Norway, Sweden, and Finland.
}

Table 2 Top 30 from the Global Sustainability Competitiveness Index (2013)

\begin{tabular}{llll}
\hline Rank & Country & Rank & Country \\
\hline 1 & Denmark & 16 & Slovenia \\
2 & Sweden & 17 & Czech Republic \\
3 & Finland & 18 & Estonia \\
4 & Norway & 19 & Spain \\
5 & Switzerland & 20 & Portugal \\
6 & Germany & 21 & Belarus \\
7 & Canada & 22 & Italy \\
8 & Ireland & 23 & Lithuania \\
9 & Austria & 24 & Australia \\
10 & Luxembourg & 25 & United Kingdom \\
11 & Netherlands & 26 & Belgium \\
12 & Japan & 27 & U.S. \\
13 & Iceland & 28 & Brazil \\
14 & New Zealand & 29 & Hungary \\
15 & France & 30 & South Korea \\
\hline
\end{tabular}

(Social Progress Imperative 2013). This index purports to measure "the capacity of a society to meet the basic human needs of its citizens, establish the building blocks that allow citizens and communities to enhance and sustain the quality of their lives, and create the conditions for all individuals to reach their full potential." Sweden was the only Scandinavian country included in the 50 countries assessed, and it received the number 1 ranking.

The Global Sustainability Competitiveness Index (SolAbility 2013) pulls together a wide array of sustainabilityrelated measurements from a number of credible organizations, including the World Bank and various UN agencies. In its 2013 ranking, 176 countries are ranked. As in the aforementioned studies, the Scandinavian and Nordic countries faired remarkably well, with Denmark at number 1; Sweden, number 2; Finland, number 3; and Norway, number 4. (The United States is number 27.) The Top 30 countries are listed in Table 2.

Furthermore, the Nordic countries consistently top the annual Transparency International Corruption Perceptions Index (see Table 3) indicating very low levels of perceived corruption across the Nordics.

While each of these studies employs a different methodology and comes at CSR and sustainability from its own angle, they all seem to indicate the same thing: by pretty much any measurement, Scandinavian countries lead the world in strong CSR and sustainability performances.

In company-level studies conducted by Gjølberg (2009), Midttun et al. (2006), and Morsing et al. (2007), a very similar finding arises: Scandinavian-based companies perform disproportionately well on the major CSR and sustainability rankings. This includes the DJSI, Global 100, 
Table 3 Top 20 from the Transparency International Corruption Perceptions Index (2013)

\begin{tabular}{llll}
\hline Rank & Country & Rank & Country \\
\hline 1 & Denmark & 11 & Luxembourg \\
1 & New Zealand & 12 & Germany \\
3 & Finland & 12 & Iceland \\
3 & Sweden & 14 & U.K. \\
5 & Norway & 15 & Barbados \\
5 & Singapore & 15 & Belgium \\
7 & Switzerland & 15 & Hong Kong \\
8 & Netherlands & 18 & Japan \\
9 & Australia & 19 & U.S. \\
9 & Canada & 19 & Uruguay \\
\hline
\end{tabular}

and FTSE4Good. As an example of this, in direct comparisons to the world's largest economy, Strand (2013a, p. 726) finds that Scandinavia-based corporations are three times more likely to be selected by the DJSI than U.S.-based corporations.

When it comes to the Global 100, we find that that Scandinavian-based corporations are significantly more likely to be selected than U.S.-based corporations. In the 2013 compilation, the Global 100 included 12 Scandinavian-based corporations (Table 4) and 10 U.S.-based corporations (Table 5).

Despite the U.S. having an economy and population that is about 16 times larger than Scandinavia, the ratio of U.S. firms to Scandinavian firms selected to the Global 100 is only 0.8 (see Table 6). Thus, we can calculate that Scandinavian corporations are 19 times more likely selected to the Global 100 than U.S. corporations.

That Scandinavian firm's outperformance of U.S. firms ranges from 3 times to 19 times, depending on the index, is indicative of the inherent differences in methodological approaches among the DJSI, Global 100, and other CSR and sustainability-related indicators. In our opinion, this provides good reason to consider these rankings as a collection rather than relying too heavily on any one individual indicator; we should be looking for general tendencies instead of focusing on absolute values. Irrespective of the range, one can plainly see the general tendency that Scandinavia-based firms are disproportionately well represented in the CSR and sustainability rankings when compared to firms in the United States.

\section{Stakeholder Engagement in Scandinavia}

Stakeholder engagement is at the heart of effective CSR and sustainability. A brief review of commonly used definitions exemplifies this. Stakeholder engagement is positioned directly at the center of the original definition of CSR offered by the European Commission (2001) and stakeholders of current and future generations are of central consideration in the Brundtland Report's definition of sustainability.

Scandinavian societies exhibit deep-seated traditions around stakeholder engagement. For example, a reverence
Table 4 Scandinavia-based companies selected for the Global 100 (2013)

\begin{tabular}{|c|c|c|c|c|c|}
\hline Count & Rank & Company name & Country & Sector & Industry group \\
\hline 1. & 3 & Statoil ASA & Norway & Energy & Energy \\
\hline 2. & 5 & Novo Nordisk A/S & Denmark & Health care & $\begin{array}{l}\text { Pharmaceuticals and } \\
\text { biotechnology }\end{array}$ \\
\hline 3. & 6 & Storebrand ASA & Norway & Financials & Insurance \\
\hline 4. & 18 & Atlas Copco AB & Sweden & Industrials & Capital goods \\
\hline 5. & 19 & Novozymes A/S & Denmark & Materials & Materials \\
\hline 6. & 27 & Scania AB & Sweden & Industrials & Capital goods \\
\hline 7. & 30 & $\begin{array}{l}\text { Telefonaktiebolaget } \\
\text { L.M. Ericsson }\end{array}$ & Sweden & Information technology & $\begin{array}{l}\text { Technology hardware } \\
\text { and equipment }\end{array}$ \\
\hline 8. & 38 & DNB ASA & Norway & Financials & Banks \\
\hline 9. & 48 & Telenor ASA & Norway & $\begin{array}{l}\text { Telecommunication } \\
\text { services }\end{array}$ & $\begin{array}{l}\text { Telecommunication } \\
\text { services }\end{array}$ \\
\hline 10. & 58 & Electrolux $\mathrm{AB}$ & Sweden & Consumer discretionary & $\begin{array}{l}\text { Consumer durables and } \\
\text { apparel }\end{array}$ \\
\hline 11. & 67 & Coloplast A/S & Denmark & Health care consumer & $\begin{array}{l}\text { Health care equipment } \\
\text { and services }\end{array}$ \\
\hline 12. & 73 & Hennes \& Mauritz AB & Sweden & Consumer discretionary & Retailing \\
\hline
\end{tabular}


Table 5 U.S.-based companies selected for the Global 100 (2013)

\begin{tabular}{|c|c|c|c|c|c|}
\hline Count & Rank & Company name & Country & Sector & Industry group \\
\hline 1. & 8 & Biogen Idec Inc. & U.S. & Health care & $\begin{array}{l}\text { Pharmaceuticals and } \\
\text { biotechnology }\end{array}$ \\
\hline 2. & 14 & Intel Corp. & U.S. & Information technology & $\begin{array}{l}\text { Semiconductors and } \\
\text { semiconductor }\end{array}$ \\
\hline 3. & 20 & Cisco Systems Inc. & U.S. & Information technology & $\begin{array}{l}\text { Technology hardware } \\
\text { and equipment }\end{array}$ \\
\hline 4. & 24 & Agilent Technologies Inc. & U.S. & Health care & $\begin{array}{l}\text { Pharmaceuticals and } \\
\text { biotechnology }\end{array}$ \\
\hline 5. & 33 & Life Technologies Corp. & U.S. & Health care & $\begin{array}{l}\text { Pharmaceuticals and } \\
\text { biotechnology }\end{array}$ \\
\hline 6. & 41 & The Clorox Company & U.S. & Consumer staples & $\begin{array}{l}\text { Household and personal } \\
\text { products }\end{array}$ \\
\hline 7. & 51 & General Electric Company & U.S. & Industrials & Capital goods \\
\hline 8. & 59 & Motorola Solutions Inc. & U.S. & Information technology & $\begin{array}{l}\text { Technology hardware } \\
\text { and equipment }\end{array}$ \\
\hline 9. & 89 & Prologis Inc. & U.S. & Financials & Real estate \\
\hline 10. & 99 & Campbell Soup Company & U.S. & Consumer staples & $\begin{array}{l}\text { Food beverage and } \\
\text { tobacco }\end{array}$ \\
\hline
\end{tabular}

Table 6 Scandinavian and U.S. comparisons and the Global 100 (Economy and Population from most recent World Bank figures)

\begin{tabular}{lll}
\hline Country & Economy $(\$ B)$ & Population $(\mathrm{M})$ \\
\hline Denmark & $\$ 235$ & 5.6 \\
Sweden & $\$ 411$ & 9.6 \\
Norway & $\$ 329$ & 5.1 \\
Scandinavia & $\$ 975$ & 20.3 \\
U.S. & $\$ 15,685$ & 316.6 \\
Ratio U.S. to Scandinavia & 16 & 16 \\
\hline
\end{tabular}

\begin{tabular}{ll}
\hline Global 100 & \# Firms \\
\hline Scandinavia & 12 \\
U.S. & 10 \\
Ratio U.S. to Scandinavia & 0.8
\end{tabular}

Likelihoods of Global 100 selection

Likelihood U.S. to Scandinavia: 0.05

Likelihood Scandinavia to U.S.:

19

for democracy may be linked to stakeholder engagement practices across Scandinavian societies. The Swedish scholar Rhenman's 1968 book Industrial Democracy and Industrial Management represents efforts to apply democratic principles within the industrial setting. It also represents the first use of the word stakeholder in the management literature anywhere in the world. According to Nasi (whose two chapters are included as an article within this special issue), Industrial Democracy was the dominant management book across the Nordic region during the 1960s and 1970s and into the 1980s. As might be expected, a number of articles selected for this special issue are focused on stakeholder engagement in Scandinavia.

Within this special issue, Ihlen and von Weltzien Hoivik track the long history of stakeholder engagement by Norwegian companies and provide some helpful comparisons with the U.S. business context throughout. The authors highlight that ongoing stakeholder engagement, driven by societal expectations and an early role of government, has been part of business consciousness in Norway for a very long time. They characterize a key distinction from the U.S. business context: business in Norway is considered "one of many institutions functioning in society, and not always seen as the most important." This use of business in society, as opposed to business and society, is a key quality of the Norwegian model in which business interests and societal interests are consistently promoted in tandem. Ihlen and von Weltzien Hoivik also point out the early role of government in driving what we would today likely refer to as CSR in a Norwegian context.

A visual depiction of business in society is offered within the stakeholder maps of Scandinavian origins shown in Figs. 1 (Swedish) and 2 (English). In these stakeholder maps, the company, state, community, and other stakeholders are depicted as sharing a jointness of interests - or what Porter and Kramer (2011) have recently referred to as shared value-through a series of overlapping ellipses representing the company and its stakeholders. Strand and Freeman's piece in this issue retraces the stakeholder concept to show its Scandinavian origins.

Within this special issue, Vidaver-Cohen and Brønn present a comprehensive study exploring the interrelationships between corporate reputation, impressions of 


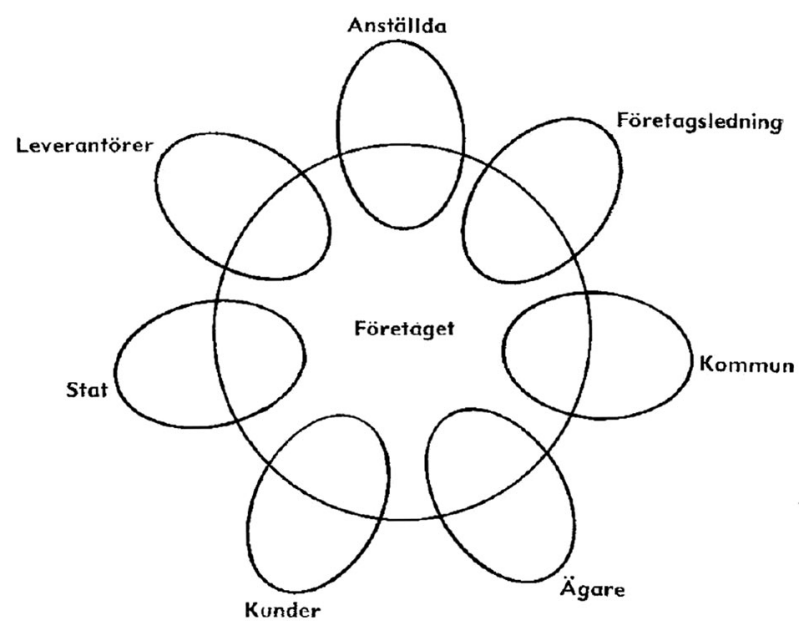

FIGUR 5 Intressenterna $i$ organisationen är de individer eller grupper som är beroende av företaget för att förverkliga sina egna personliga mål och av vilka företaget är beroende för sin existens.

Fig. 1 Stakeholder map (Swedish). Reprinted from Företagsdemokrati och företagsorganisation, by Rhenman (1964)

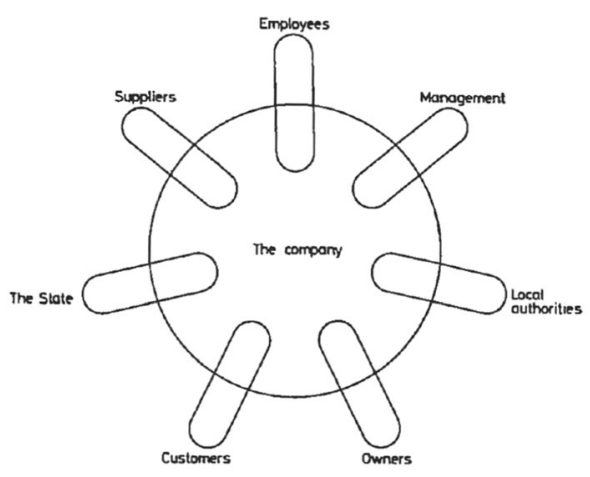

Figure 5. The stakeholders in an organization are the individuals or groups dependent on the company for the realization of their personal goals and on whom the company is dependent for its existence.

Fig. 2 Stakeholder map (English) from Industrial Democracy and Industrial Management, by Rhenman (1968)

corporate responsibility, and stakeholder support across (and between) Scandinavian countries. Interestingly, the authors find that across Denmark, Norway, and Sweden, perceptions of a firm's CSR performances emerged as the strongest predictors of both corporate reputation and the degree to which a firm enjoys stakeholder supporteclipsing considerations of financial performance, innovation, and even quality of products and services.

Hence, Vidaver-Cohen and Brønn find stakeholder support to be an outcome of perceptions of CSR performances; elsewhere, CSR performances are considered an outcome of stakeholder engagement. In practice, CSR performances and stakeholder engagement are likely tightly commingled where distinguishing inputs from outputs is not easy, if possible at all. Vidaver-Cohen and
Brønn provide a useful analysis demonstrating the general congruence of these factors.

\section{Creating Shared Value: A Scandinavian Concept?}

The theory and practice of stakeholder engagement are inexplicably similar to the concept of shared value proposed in the recent Harvard Business Review article by Porter and Kramer (2011), titled "Creating Shared Value." This represents an argument made by Strand and Freeman in their article "Scandinavian Cooperative Advantage" included within this special issue. Once these authors trace the roots of stakeholder theory and strong stakeholder engagement practices to deep Scandinavian roots, they go further by contending that "creating shared value is arguably a concept of Scandinavian origins." Porter and Kramer's (2011) "Creating Shared Value" is one of the most widely read and influential articles related to the fields of CSR and sustainability in recent years, fueled no doubt in large part to the prominence of its lead author, strategicmanagement guru Michael Porter, and thus we more thoroughly consider these issues here.

With the introductory statement "the purpose of the corporation must be redefined as creating shared value, not just profit per se," Porter and Kramer (2011, p. 76) seemingly issue a call to break tradition with the neoclassical economist view of the corporation epitomized by Milton Friedman's $(1962 / 2002,1970)$ assertion that the sole purpose of the corporation is to maximize profits and thereby shareholder wealth. The narrative that shareholderwealth maximization is the sole purpose of the corporation has long enjoyed status as the dominant narrative about role of the corporation in the U.S. business (Ghoshal 2005; Stout 2012). Hence, an apparent break from this by a mainstream strategist with the influence of Michael Porter is noteworthy: it presents the potential to influence mainstream thinking. Porter and Kramer state:

Shared value offers corporations the opportunity to utilize their skills, resources, and management capability to lead social progress in ways that even the best-intentioned governmental and social sector organizations can rarely match. In the process, businesses can earn the respect of society again. (2011, p. 77).

To support their claim that creating shared value is essentially a restatement of stakeholder theory, Strand and Freeman highlight core phrases from "Creating Shared Value" that read as strikingly similar to concepts from the stakeholder-theory literature, including the use of the stakeholder language. For example, Porter and Kramer (2011, p. 76) describe creating shared value as "joint 
company and community value creation" that is "well connected to the goals of all stakeholders." This statement effectively rehashes the long-standing "jointness of interests" principle of stakeholder theory that states the company and its stakeholders have joint (i.e., shared) interests. Stakeholder-theory proponents such as Freeman et al. (2010) have long contended that great companies recognize that they share interests with their stakeholders and that these companies continuously build and reimagine these intersections in an effort to create more value for more stakeholders, ultimately benefitting companies and society. This is effectively the core thesis of creating shared value.

In a recent California Management Review article, Crane et al. (2014) support the argument of Strand and Freeman by leveling the charge that creating shared value is "unoriginal" and appears strikingly similar to the literature stream associated with stakeholder theory. Crane et al. state:

The framing of the shared value concept appears to ignore a well-developed stream of work around creating value within the stakeholder management literature. Instrumental stakeholder theory [Donaldson and Preston 1995], for instance, which contends that "adherence to stakeholder principles and practices achieves conventional corporate performance objectives as well or better than rival approaches" is largely synonymous with the characterization of CSV as "creating economic value in a way that also creates value for society by addressing its needs and challenges" [Porter and Kramer 2011, p. 64]. Moreover, even the language of value creation has been a major feature of the work of Ed Freeman, stakeholder theory's leading advocate, over the past decade or sothe key principle here being that "creating value for stakeholders creates value for shareholders." It is difficult to see where CSV differs in any substantial way from this literature, yet it remains wholly unacknowledged by Porter and Kramer in any of their work to date. (2014, p. 135).

The link between stakeholder theory and creating shared value appears quite clear; however, this in and of itself of course does not prove a Scandinavian link to create shared value. That link is made within the content of the Nasi and the Strand and Freeman articles included within this special issue, where the foundational Scandinavian contributions to stakeholder theory are made evident. This includes the introduction of the word stakeholder and the first ever stakeholder map in the management literature, both originating in Scandinavia. One of the most important contributions from these stakeholder offerings originating from Scandinavia is the perspective of an "outside-in" approach to strategic management. This may also be where a close

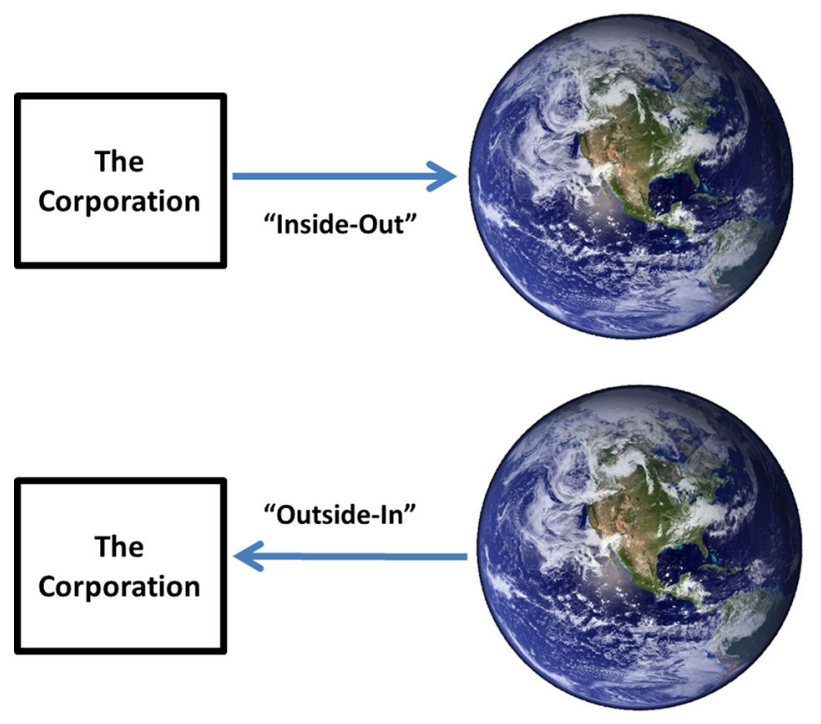

Fig. 3 Differing views on corporate strategy

connection between the previous stakeholder offerings from Scandinavia and the more recent creating sharedvalue concept become most apparent.

As depicted in Fig. 3, an "inside-out" perspective of corporate strategy entails a corporation first considering its own interests and then its interests' interactions with the world. Said another way, an inside-out perspective means that a corporation adopts a strategy to consider how it can sell more of its products and services to the world. This inside-out perspective is encouraged in the neoclassical economist view of the corporation in which the sole purpose of the corporation is to maximize profits. In contrast, an outside-in perspective of corporate strategy begins with a consideration of the world's needs and then walks back to consider how the corporation can best meet those needs. In partnership with Scandinavian industry, Scandinavian management theorists have demonstrated an embracement of the outside-in approach to corporate strategy. Scandinavian scholars Eric Rhenman and Bengt Stymne are considered pioneers in this outside-in consideration of the firm with their development of these strategic-management concepts (Freeman et al. 2010, p. 48). The concept of creating shared value is decidedly far more outside-in than previous offerings from mainstream strategic-management theories.

Porter and Kramer (2014) refute the charge of unoriginality with a claim that "substantial changes" have occurred as result of their article. In full, they state:

Andrew Crane's critique of Creating Shared Value acknowledges the wide and positive reception our article has received, but at the same time contends that we have said nothing new. This is puzzling, 
especially given the substantial changes in behavior in corporations around the world, both large and small, that have come as a direct result of the article. (2014, p. 149).

In response, we contend that Strand and Freeman's claim that "creating shared value is arguably a concept of Scandinavian origins" is plausibly justified when one considers the apparent links between creating shared value and stakeholder theory, coupled with the foundational Scandinavian contributions to stakeholder theory. That said, given the firepower of the Michael Porter name, the "Creating Shared Value" article has helped to raise important discussions to a heights not previously experienced. As Strand and Freeman contend serves as "further reason to delve more deeply into company-stakeholder cooperation in a Scandinavian context today and from which ample examples of creating shared value can be found." Porter et al. (2012, pp. 6-7) have done so already, citing examples from the Danish pharmaceutical company Novo Nordisk that show the company having long demonstrated a "shared value strategy." They state:

Two decades ago, Novo Nordisk initiated a long-term China market growth strategy centered on improving diabetes care. Its shared value strategy was clear: by investing in physician training, patient education, and local production, the company believed it would dramatically improve the diagnosis of diabetes, a disease that was often unrecognized, and increase the demand for its insulin products. Helping to improve diabetes diagnosis, care, and treatment would not only improve the lives of millions of Chinese citizens but would also improve the company's bottom line.

One may readily argue that this example of a sharedvalue strategy offered by Porter and company serves as further evidence that the concept of creating shared value has been in existence for some time in Scandinavia.

Arguably, the publication of "Creating Shared Value" presented the promise to shift language and attention in strategic management away from the traditional focus on competition and dominance toward language and attention toward cooperation and mutually beneficial value creation. The focus on competition between stakeholders is epitomized by the so-called Porter's 5 Forces shown in Fig. 4 (Porter 1979, 2008). As example of the difference between the 5 Forces model and the traditional approach advocated in Scandinavia, consider how the company and its stakeholders of suppliers and customers are depicted in starkly different terms. The Scandinavian stakeholder maps in Figs. 1 and 2 depict the company, its suppliers, and its customers as having shared interests, whereas in the 5 Forces model, the interests of a company and its suppliers
The Five Forces That Shape Industry Competition

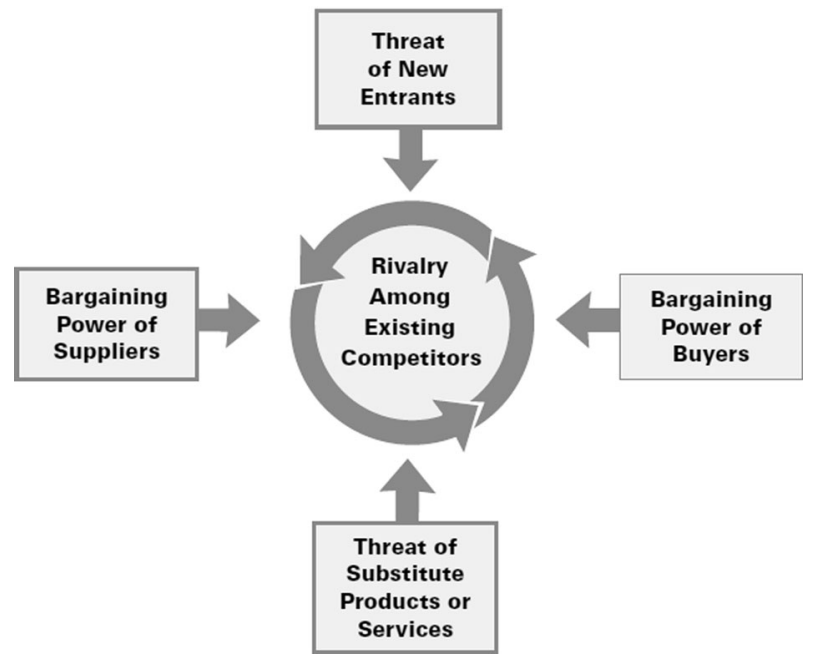

Fig. 4 Porter's 5 forces. Reprinted with permission from "The Five Competitive Forces That Shape Strategy," by Porter (2008), Harvard Business Review. Copyright (C) 2008 by Harvard Business Publishing; all rights reserved

and customers are shown in direct competition. Therefore, somewhat ironically, Porter and Kramer's most recent "Creating Shared Value" offering may be the best hope to unseat the competitive, conflict-based view of strategic management that Michael Porter himself helped to create (Strand 2014c)

\section{Institutional Influencers on CSR and Sustainability in Scandinavia}

It is difficult, if not impossible, to decouple institutional structures from the cultural contexts that created them and, in turn, are shaped by them. Questions such as "Does culture shape law?" and "Does law shape culture?" are each correctly answered yes. ${ }^{6}$ Cultural norms and institutional structures are tightly commingled and serve to influence and give rise to new cultural norms and institutional structures. For example, Norway's 2005 law mandating that boards of directors of public corporations have at least $40 \%$ female representation was at least in part a result of a cultural context in which a certain degree of gender equality is valued, enabling such a political law to be passed and enacted in a democratic society. Looking ahead, this regulation will likely influence cultural norms as it becomes more commonplace for women to hold formalized positions of power (Strand 2009). Therefore, within this section, we artificially create a sharp distinction

\footnotetext{
$\overline{{ }^{6} \text { See Mezey }}$ (2001) and Rosen (2006), for further discussions.
} 
between institutional structures and cultural norms, but do so for purposes of discussion only. In the next section, we will focus on cultural norms in a Scandinavian context.

For the better part of the previous century, the political parties broadly characterized as social democratic have dominated the ruling class across the governments of Scandinavian societies (Castles 1978/2009). It requires but a short leap to associate the ideals of the Scandinavian social democracies with sustainability and CSR agendas. Through attention to the promotion of egalitarian policies and consideration for the well being of current and future generations, Scandinavian social democracies espouse the virtues of stakeholder engagement, which has led to some of the highest levels of social and environmental regulations and programs on the planet. Midttun et al. (2006), Gjølberg (2009), and Gjølberg (2010) contend that the institutional structures put in place during the decades of social democratic rule are a major driving force behind the superior sustainability and CSR performances by Scandinavian companies. Campbell (2007, p. 963) summarizes these arguments:

The World Economic Forum [2003] recently ranked three Scandinavian countries-Finland, Sweden, and Denmark-among the four most competitive economies in the world. It also ranked them very high in terms of the strong ethical behavior of their national corporations. All three are very open economies and, therefore, highly susceptible to the economic pressures of globalization, and all three have the sorts of institutions that I have argued will facilitate socially responsible corporate behavior.

These Scandinavian countries have much state regulation, self-regulation, corporatist bargainingincluding well-organized business associations - and other mechanisms for institutionalized dialogue among firms and their stakeholders ... So far, these institutions have persisted despite increased globalization.

However, in even more recent years, the Scandinavian governments have adopted approaches described as more "laissez-faire" that resemble policies of the United States. Morsing (2011) notes that this move and the comparatively high degree of engagement by Scandinavian governments to encourage CSR and sustainability activities by corporations may be considered directly related to the recent trend of Scandinavian governments to withdraw from areas that were previously public responsibilities. Within this special issue, Vallentin provides an account of the Danish government's efforts since the early 1990s to encourage firms' CSR engagement. The government utilized CSR in the 1990 s to promote the social inclusiveness agenda, the pivotal concern of which was social integration through the domestic labor market. In the early 2000s, the government utilized CSR to promote an agenda primarily concerned with the national competitiveness and growth. Around 2012, Vallentin notes the Danish government shifted to using CSR to address issues associated with global governance and accountability challenges. While Vallentin's primary intention is to highlight how the Danish government has differed rather significantly over the past decades in the objectives it intends to achieve through the promotion of CSR, in all approaches, the Danish state has demonstrated a desire to utilize CSR as a means through which to shift ownership of a public issue to the private sector.

This represents a major new area for research that is directly associated with discussions regarding movement from implicit CSR toward explicit CSR in the Scandinavian context. Matten and Moon (2008) identify the implicit-explicit CSR framework as a way to consider shifting institutional contexts that may encourage firms to engage implicitly or more explicitly with CSR. They summarize this framework as follows:

By "implicit CSR," we refer to corporations' role within the wider formal and informal institutions for society's interests and concerns. Implicit CSR normally consists of values, norms, and rules that result in (mandatory and customary) requirements for corporations to address stakeholder issues and that define proper obligations of corporate actors in collective rather than individual terms.

By "explicit CSR," we refer to corporate policies that assume and articulate responsibility for some societal interests. They normally consist of voluntary programs and strategies by corporations that combine social and business value and address issues perceived as being part of the social responsibility of the company. (2008, pp. 409-410).

Historically speaking, Scandinavian firms have demonstrated traditions of implicit engagement with CSR. For example, within this special issue, Ihlen and von Weltzien Hoivik discuss how the label CSR has only recently been applied to the activities of Norwegian firms, whereas the implicit addressing of stakeholder concerns has a long tradition in Norway and is encouraged by the dominant cultural norms and institutional structures. They argue that CSR is only a recent term in Norway that has been introduced into the lexicon through forces coming from outside of Scandinavia-namely the United States. Similarly, Carson, Hagen, and Sethi's piece utilizes the implicit/ explicit CSR framework to explore and explain how the Norwegian firms HÅG and Norsk Hydro engage with CSR. They, too, highlight the companies' more recent tendency 
to explicitly apply the CSR label to their efforts, even though these companies historically just did the CSR work without labeling it as such. One may characterize all of this in terms of Scandinavian firms having traditionally focused on "walking the walk," whereas U.S. firms have traditionally focused on "talking the talk."

So what might this shift-from implicit CSR toward explicit CSR in the Scandinavian context-mean? Gjølberg (2009) contends that Scandinavian firms can successfully parlay their strong implicit CSR traditions into explicit CSR strategies and thus take advantage of the existing societal and institutional foundations that have already been laid in support of strong stakeholder engagement and related CSR performances. However, a tension becomes apparent when one considers Gjølberg's prescription in concert with Vidaver-Cohen and Brønn's concluding suggestion: that impressions by Scandinavian citizens of Scandinavian firms behaving responsibly "may be weakened when firms 'import' culture and values from abroad." In other words, explicit CSR is a construct whose origins come from outside of Scandinavia-namely, the United States where the emphasis is on "talking the talk." Given that Scandinavian firms have historically largely focused on "walking the walk," Gjølberg seems to prescribe that Scandinavian firms learn about "talking the walk." However, Vidaver-Cohen and Brønn warn against the potential downside of such talk given that boasting on their own behalf is not a norm for Scandinavian firms and thus a fear that a focus on the "talking" may negatively affect the "walk." Similarly, Morsing et al. (2008) found that Danish citizens wanted Danish firms to engage in socially responsible activities (i.e., walking the walk) but not talk too much about them. The suite of challenges associated with these issues presents a field of inquiry for further studies.

Additional potential institutional influencers on CSR and sustainability in Scandinavia that merit further investigations include mandatory employee representation on boards of directors (BODs), longer term shareholders and more consolidated share ownership, and flatter pay structures (Thomsen and Conyon 2012). Mandatory employee representation on BODs represents institutionalized stakeholder engagement between the corporation and its stakeholder beyond shareholders. Moreover, employees tend to stay with a company far longer than the average share of a public company is held whereby this may also help to encourage longer term perspectives (Stout 2012). Furthermore, a longer term perspective is embedded in Scandinavian ownership structures given that ownership of public firms tends to be much more consolidated and where the state and large foundations often hold large percentages of shares in firms for extended periods of time (Thomsen and Conyon 2012). Finally, flatter pay structures in a
Scandinavian context are evidenced by much more modest CEO to average worker pay ratios. For example, in Scandinavia, average CEO to worker pay ratio is reported to be in the $10-30 \times$ range, whereas in the U.S. this range is $300-500 \times$ (Randøy and Nielsen 2002; Walsh 2008). This proxy of organizational flatness may be considered an indicator of greater likelihood for stakeholder engagement given the relatively low power distance between individuals. The CEO to worker pay ratio will likely be increasingly drawn into the CSR and sustainability debates as global attention to increasing income inequality continues to grow (Piketty 2014) and hence draw further attention to Scandinavia.

\section{Scandinavian Cultural Influences on CSR and Sustainability}

A popular T-shirt sold by the satirical faux news outlet The Onion declares "Stereotypes Are a Real Time-Saver" across its chest (see Fig. 5). In this section, we engage with stereotypes, while heeding the implied warning from this satirical statement that stereotypes are often deployed as a sort of cultural shortcut. Instead, we draw inspiration to use stereotypes as a starting point for conversation to go "beyond" stereotyping as Osland and Bird (2000) describe to utilize stereotypes as a starting point for inquiry. In this manner, instead of engaging with stereotypes, we can more prosperously discuss cultural generalizations, characterizations, and tendencies that may be more likely to be experienced in a Scandinavian context-and then consider what this may means when considering issues of CSR and sustainability. While doing so we acknowledge our interpretations are subject to debate-and we encourage further debate to ensue.

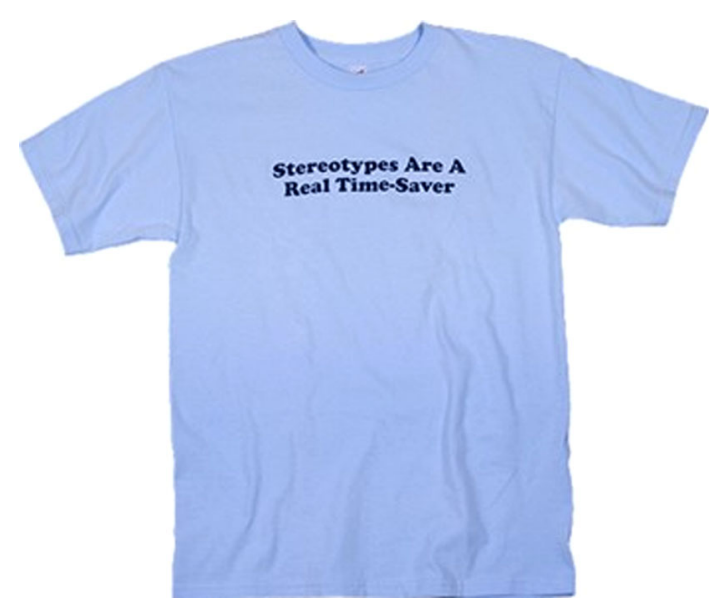

Fig. 5 Popular expression regarding stereotypes from http://store. theonion.com 
The aforementioned expression "Scandinavian management" is heavily laden with characterizations of Scandinavian culture. In these descriptions, Scandinavian management is depicted as encouraging cooperation, consensus building, participation, power sharing, consideration of the well being of stakeholders beyond just shareholders or some narrowly defined constituency, humility, and trustworthiness (Grennes 2003, 2011; Morsing et al. 2007).

Furthermore, Scandinavian managers and members of the business community have been described as having a high disdain for "face-saving" (House et al. 2004). In other words, making superfluous efforts to avoid looking bad is not considered respectable. Thus, one may readily argue that Scandinavian managers have a greater willingness to engage with the so-called wicked problems that may open the managers up to a suite of messy issues for which they do not have answers (Strand 2014b). While engagement does not necessarily mean an acceptable outcome will be achieved, when it comes to CSR and sustainability challenges like child labor and global warming, not engaging with these issues almost certainly guarantees that nothing will be achieved. These sorts of CSR and sustainability challenges are aptly described as wicked problems because no one clear solution can be applied by any one actor. Rather, ongoing cooperation by many actors is often necessary (Strand 2013b).

Arguably, the most well known of research studies done in the name of culture are those by the Dutch psychologist Geert Hofstede. Based upon responses to IBM personnel surveys from 100,000 IBM employees across 60 countries during the 1960s, Hofstede (1980/2001) attempted to describe cultural variations around the world. Comparing employee responses by country, Hofstede identified five cultural dimensions scored from 0 (low) to 100 (high) that described what he found to be the most relevant differences between cultures. Hofstede's five cultural dimensions are individualism/collectivism, power distance, masculinity/ femininity, uncertainty avoidance, and long/short-term orientation. One of the most discussed (and controversial) of these cultural dimensions is the masculinity/femininity dimension. We will consider this dimension further because Scandinavian countries were categorized as having the least masculine (i.e., most feminine) cultures in the world, with Denmark scoring 16; Norway, 8; and Sweden, 5.

From this research, Hofstede first published Culture's Consequences in 1980. This remains arguably the most influential work related to cultural studies in business. It is also perhaps the most criticized (Ailon 2008; Osland and Bird 2000). Some of these criticisms accuse Hofstede's work of treating culture as static, of approaching it essentialistically as a "software of the mind" whereby individuals are considered to have no agency of their own but rather are dupes, and of reducing culture to a small suite of dimensions that can be applied numerically. Critics say that this approach is at best overly simplistic and at worst potentially damaging.

We keep these criticisms closely in mind and thus intend to use Hofstede's work as a starting point for inquiry in a manner consistent with Osland and Bird's (2000) utilization of what they call "sophisticated stereotyping" as a starting point. Given Scandinavia's characterization as a feminine culture, we focus on Hofstede's masculine and feminine cultural dimension. Cultures deemed masculine are societies with distinct social gender roles: men are supposed to be assertive, tough, and focused on material success, and women are supposed to be more modest, tender, and concerned with the quality of life. The best way to solve conflict in a masculine society is through the use of force ("may the best man win"). Competition and aggressiveness are seen as positive. With a score of 95, Japan was identified as a heavily masculine culture. Italy and the United States also scored as masculine with values of 70 and 62, respectively.

Cultures deemed feminine are societies in which social gender roles overlap: both men and women are supposed to be modest, tender, and concerned with the quality of life. Conflict is considered to be best solved through negotiation and compromise. Cooperation is seen positively, where the building of trust between stakeholders is highly valued. Again, the Scandinavian countries were categorized as the most feminine cultures in the world and when one considers the characteristics of Scandinavian management, they are generally consistent with the feminine cultural dimension.

When one takes a step back to consider the CSR and sustainability agenda in which engagement with stakeholders and concern for the well being of future generations are central, one could readily argue that the agenda tends to align well with the description of feminine cultures. In a recent study (Strand 2010), in which CSR performance was compared to Hofstede's masculinity/ femininity dimension, this is precisely what was found as is described next.

In 2009, Gjølberg published an index that measured the over- and under-representation of companies in these three CSR indexes. Twenty OECD countries' CSR performance was rated on a scale from -10 (low) to +10 (high), taking into account the relative size of each nation's economy. In this index, the feminine Scandinavian countries fared well, with Denmark, Norway, and Sweden each having an overrepresentation of companies with strong CSR performance. The bulk of the masculine countries, including the United States, were largely underrepresented, thus indicating poorer overall CSR performance. 
Fig. 6 CSR performance versus masculine/feminine cultures $\left(p<.05 ; R^{2}=0.20\right)$
CSR performance vs Masculine Culture

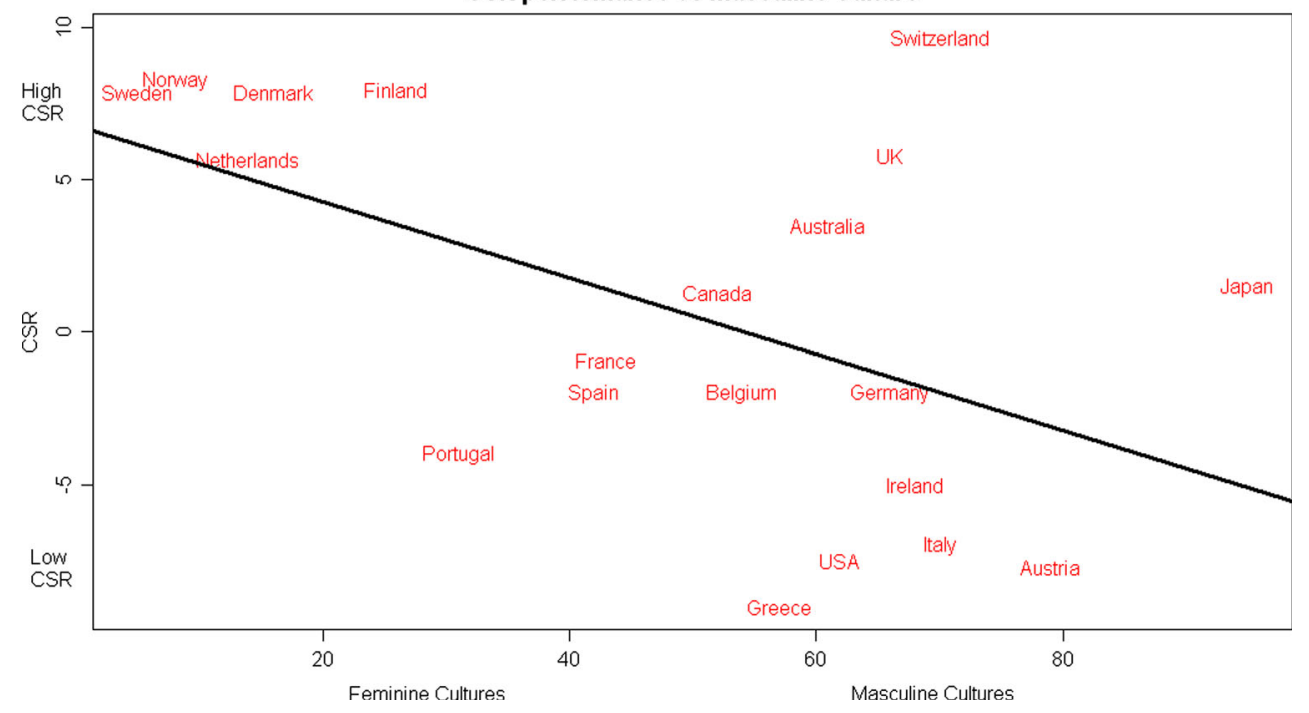

Through a regression analysis of the masculinity/femininity cultural dimension plotted against the CSR performance index shown in Fig. 6, support is given for the intuition that feminine cultures are on the whole more supportive of stronger CSR performance than are masculine cultures. Here the $p$ value is less than .05 and an $R^{2}$ is .20 , with the masculine/feminine dimension as the independent variable and CSR performance as the dependent (while controlling for gross domestic product per capita). At the very least, one could argue that this is a good indication that feminine cultures are generally more supportive of stronger CSR performance.

Intuitively, it makes sense that feminine cultures-with their embracement of cooperation and concern for quality of life-would, on the whole, have stronger CSR and sustainability performances than masculine cultures. One type of CSR or sustainability-related activity that is more likely realized through an embrace of cooperation is partnerships between corporations and credible nongovernmental organization-like Save the Children, WWF, or Amnesty International- to jointly take on difficult environmental or social challenges that neither organizations could solve on its own. These activities depend on cooperation and the ability to build trust between organizations.

In this special issue, Strand and Freeman propose the concept of "Scandinavian cooperative advantage" by which they define as "the general tendency for companies in a Scandinavian context to implement a value creating strategy based on cooperating with their stakeholders that results in superior value creation for the companies and their stakeholders." For this reason Strand and Freeman (erratum) declare "It would seem that Scandinavian stakeholder capitalism is a closer model to 'conscious capitalism' (Mackey and Sisodia 2013) than is experienced elsewhere, such as the U.S."

\section{Conclusion}

In this article, we have established that by pretty much any way one measures it, Scandinavian countries and Scandinavian companies lead the world in strong CSR and sustainability performances. We highlighted institutional and cultural factors that serve as contributors to these performances, most notably the deep-seated traditions of stakeholder engagement that can be found across Scandinavia that encourages a cooperative approach to business. In sum, we contend that Scandinavia can effectively serve as inspiration for CSR and sustainability and we intend to help draw greater attention to the Scandinavian context for further research.

However, we call this attention to also help raise interest for exploring potentially looming challenges to these Scandinavian performances. With respect to discussions about explicit CSR, as Scandinavian firms feel greater pressure for "talking the walk" might this detrimentally affect the walking? Said another way, "talking the walk" is not a straightforward process of disseminating but rather talking itself leads a number of social dynamics influencing the way business in society is perceived. So, as Morsing and Strand (2013) point out, there exists an important research agenda to be explored further: what is Scandinavia doing to CSR and what is CSR doing to Scandinavia? In the Scandinavian context where humility has traditionally been valued, what might happen when this is supplanted with boasting about performances? Relatedly, as Scandinavian governments continue to withdraw from areas of social and 
environmental concern, they increasingly call upon Scandinavian firms to fill the void. To the degree that Scandinavian governments and related institutional forces have been a driver for CSR and sustainability performances of Scandinavian firms, how might this continued withdrawal impact future CSR and sustainability performances?

Without concerted considerations to better understand the contributing factors for how Scandinavian countries and firms have effectively achieved such strong CSR and sustainability performances, a grave risk is apparent that these performances may erode over time. Therefore, we seek to establish a global research paradigm dedicated to studying CSR and sustainability in a Scandinavian context in part to address this.

Acknowledgments We would like to offer our most sincere gratitude to the large number of volunteer reviewers who kindly offered their time and expertise during the review process of this special issue. Without you, this special issue would not have been possible. Thank you. We would also like to thank Andreas Rasche and Mette Morsing for providing peer reviews for this article.

\section{References}

Ailon, G. (2008). Mirror, mirror on the wall: Culture's consequences in a value test of its own design. Academy of Management Review, 33(4), 885-904.

Beauchamp, T. L., Bowie, N. E., \& Arnold, D. G. (2009). Ethical theory and business (8th ed.). Upper Saddle River, NJ: Pearson Prentice Hall.

Bondeson, U. (2003). Nordic moral climates: Value continuities and discontinuities in Denmark, Finland, Norway, and Sweden. New Brunswick, NJ: Transaction.

Bowie, N. E. (1999). Business ethics: A Kantian perspective. Oxford: Blackwell.

Campbell, J. L. (2007). Why would corporations behave in socially responsible ways? An institutional theory of corporate social responsibility. Academy of Management Review, 32(3), 946-967.

Carroll, A. B. (1998). The four faces of corporate citizenship. Business and Society Review, 100(1), 1-7.

Carroll, A. B. (1999). Corporate social responsibility evolution of a definitional construct. Business and Society, 38(3), 268-295.

Castles, F. (1978/2009). The social democratic image of society: A study of the achievements and origins of Scandinavian social democracy in comparative perspective. Routledge, New York.

Castles, F. G. (1993). Families of nations: Patterns of public policy in Western democracies. Aldershot: Dartmouth.

Chatterji, A., \& Levine, D. (2006). Breaking down the wall of codes: Evaluating non-financial performance measurement. California Management Review, 48(2), 1-23.

Chatterji, A., Levine, D., \& Toffel, M. (2009). How well do social ratings actually measure corporate social responsibility? Journal of Economics \& Management Strategy, 18(1), 125-169.

Crane, A., \& Matten, D. (2007). Business ethics: Managing corporate citizenship and sustainability in the age of globalization. Oxford: Oxford University Press.

Crane, A., Palazzo, G., Spence, L. J., \& Matten, D. (2014). Contesting the value of "creating shared value". California Management Review, 56(2), 130-153.
Dahlsrud, A. (2008). How corporate social responsibility is defined: An analysis of 37 definitions. Corporate Social Responsibility and Environmental Management, 15(1), 1-13.

Davis, J. H., Schoorman, F. D., \& Donaldson, L. (1997). Toward a stewardship theory of management. Academy of Management Review, 22(1), 20-47.

Derry, T. K. (1979). A history of Scandinavia. Minneapolis: University of Minnesota.

Donaldson, T., \& Preston, L. E. (1995). The stakeholder theory of the corporation: Concepts, evidence, and implications. Academy of Management Review, 20(1), 65-91.

Dyllick, T., \& Hockerts, K. (2002). Beyond the business case for corporate sustainability. Business Strategy and the Environment, 11(2), 130-141.

Economist. (Feb 2, 2013). The Nordic countries: The next supermodel.

Economist. (Jan 19, 2008). Just good business: A special report on corporate social responsibility.

Elkington, J. (1999). Cannibals with forks. Oxford: Capstone.

Freeman, R. E. (1984/2010). Strategic management: A stakeholder approach. Pitman, Boston.

Freeman, R. E., Harrison, J., Wicks, A., Parmar, B., \& de Colle, S. (2010). Stakeholder theory: The state of the art. Cambridge: Cambridge University Press.

Friedman, M. (1962/2002). Capitalism and freedom. University of Chicago Press, Chicago.

Friedman, M. (1970). The social responsibility of business is to increase its profits. New York Times Magazine, 33, 122-126.

Ghoshal, S. (2005). Bad management theories are destroying good management practices. Academy of Management Learning \& Education, 4(1), 75-91.

Gjølberg, M. (2009). The origin of corporate social responsibility: Global forces or national legacies? Socio-economic Review, 7(4), 605-637.

Gjølberg, M. (2010). Varieties of corporate social responsibility (CSR): CSR meets the "Nordic model". Regulation \& Governance, 4, 203-229.

Gond, J., \& Crane, A. (2010). Corporate social performance disoriented: Saving the lost paradigm? Business and Society, 49(4), 677-703.

Grennes, T. (2003). Scandinavian managers on Scandinavian management. International Journal of Value-Based Management, 16, $9-21$.

Grennes, T. (2011). Will the "Scandinavian leadership model" survive the forces of globalisation? A SWOT analysis. International Journal of Business and Globalisation, 7(3), 332-350.

Gupta, V., \& Hanges, P. (2004). Regional and climate clustering of societal cultures. In R. House, P. Hanges, M. Javidan, P. Dorfman, \& V. Gupta (Eds.), Culture, leadership, and organizations: The GLOBE study of 62 societies (pp. 178-218). Thousand Oaks, CA: Sage.

Guthey, E., \& Morsing, M. (2013). CSR and the mediated emergence of strategic ambiguity. Journal of Business Ethics, 120(4), 555-569.

Hirsch, P. M., \& Levin, D. Z. (1999). Umbrella advocates versus validity police: A life-cycle model. Organization Science, 10(2), 199-212.

Hofstede, G. (1980/2001). Culture's consequences, 2nd edition. SAGE, Beverly Hills, CA.

House, R., Hanges, P., Javidan, M., Dorfman, P., \& Gupta, V. (Eds.). (2004). Culture, leadership, and organizations: The GLOBE study of 62 societies. Thousand Oaks, CA: Sage.

Mackey, J., \& Sisodia, R. (2013). Conscious capitalism: Liberating the heroic spirit of business. Cambridge, MA: Harvard Business Press. 
Matten, D., \& Crane, A. (2005). Corporate citizenship: Toward an extended theoretical conceptualization. Academy of Management Review, 30(1), 166-179.

Matten, D., \& Moon, J. (2008). "Implicit" and "explicit" CSR: A conceptual framework for a comparative understanding of corporate social responsibility. Academy of Management Review, $33(2), 404-424$.

Mezey, N. (2001). Law as culture. Yale Journal of Law \& the Humanities, 13, 35.

Midttun, A., Gautesen, K., \& Gjølberg, M. (2006). The political economy of CSR in Western Europe. Corporate Governance, 6(4), 369-385.

Morsing, M. (2011). State-owned enterprises: A corporatization of governments? Management Communication Quarterly, 25, 710-717.

Morsing, M., Midttun, A., \& Palmås, K. (2007). Corporate social responsibility in Scandinavia-a turn towards the business case? In S. May, G. Cheney, \& J. Roper (Eds.), The debate over corporate social responsibility (pp. 98-127). London: Oxford University Press.

Morsing, M., Schultz, M., \& Nielsen, K. U. (2008). The "Catch 22" of communicating CSR: Findings from a Danish study. Journal of Marketing Communications, 14(2), 97-111.

Morsing, M., \& Strand, R. (2013). CSR and beyond. A nordic perspective. Book Review. Corporate Communications: an International Journal.

Nordstrom, B. (2000). Scandinavia since 1500. Minneapolis: University of Minnesota Press.

Osland, J. S., \& Bird, A. (2000). Beyond sophisticated stereotyping: Cultural sensemaking in context. The Academy of Management Executive, 14(1), 65-77.

Østergård, U. (1997). The geopolitics of Nordic identity: From composite states to nation states. In $\varnothing$. Sørensen \& B. Stråth (Eds.), The cultural construction of Norden (pp. 25-71). Oslo: Scandinavian University Press.

Piketty, T. (2014). Capital in the 21st Century. Cambridge: Harvard University Press.

Porter, M. E. (1979). How competitive forces shape strategy. Harvard Business Review, 57(2), 137-145.

Porter, M. E. (2008). The five competitive forces that shape strategy. Harvard Business Review, 86(1), 25-40.

Porter, M. E., Hills, G., Pfitzer, M., Patscheke, S. and Hawkins, E. (2012). Measuring shared value: How to unlock value by linking social and business results. www.fsg.org/Portals/0/Uploads/ Documents/PDF/Measuring_Shared_Value.pdf.

Porter, M., \& Kramer, M. (2006). Strategy and society: The link between competitive advantage and corporate social responsibility. Harvard Business Review, 84(12), 78-92.

Porter, M. E., \& Kramer, M. R. (2011). Creating shared value. Harvard Business Review, 89(1/2), 62-77.

Porter, M. E., \& Kramer, M. (2014). A response to Andrew Crane et al.' s article. California Management Review, 56(2), 149-151.

Randøy, T., \& Nielsen, J. (2002). Company performance, corporate governance, and CEO compensation in Norway and Sweden. Journal of Management and Governance, 6(1), 57-81.

Rhenman, E. (1964). Företagsdemokrati och företagsorganisation. Stockholm: Thule.

Rhenman, E. (1968). Industrial democracy and industrial management. London: Tavistock.
Rosen, L. (2006). Law as culture: An invitation. Princeton, NJ: Princeton University Press.

Schwartz, M. S., \& Carroll, A. B. (2008). Integrating and unifying competing and complementary frameworks: The search for a common core in the business and society field. Business and Society, 47(2), 148-186.

Social Progress Imperative. (2013). Social progress index. http:// www.socialprogressimperative.org. Retrieved 1 May 2014.

SolAbility. (2013). Global sustainable competitiveness index. http:// www.solability.com/pdfs/Sustainable_Competitiveness_Index_ 2013.pdf. Retrieved 1 May 2014.

Stiglitz, J., Sen, A., \& Fitoussi, J. P. (2009). The measurement of economic performance and social progress revisited. Reflections and overview. Paris: Commission on the Measurement of Economic Performance and Social Progress.

Stout, L. A. (2012). The shareholder value myth: How putting shareholders first harms investors, corporations, and the public. San Francisco, CA: Berrett-Koehler.

Strand, R. (2009). Leaders in touch with feminine side. Financial Times (June 18): 8.

Strand, R. (2010). Kultur og CSR: Fordelene ved den skandinaviske tilgang til CSR [Culture \& CSR: Embracing the Scandinavian approach to $\mathrm{CSR}]$. In $\mathrm{B}$. Ledelseshåndbøger (Ed.), Corporate social responsibility (pp. 1-14). Copenhagen: Børsen.

Strand, R. (2011). Toward sustainable sustainability learning: Lessons from a US MBA Study abroad program in Scandinavia. Journal of Strategic Innovation and Sustainability, 7(2), 41-63.

Strand, R. (2013a). The chief officer of corporate social responsibility: A study of its presence in top management teams. Journal of Business Ethics, 112(4), 721-734.

Strand, R. (2013b). Scandinavian cooperative advantage: The case of IKEA. In S. Khan, \& W. Amann (eds.), World humanism: Crosscultural perspectives on ethical practices in organizations, (pp. 63-80). Palgrave Macmillan, New York.

Strand, R. (2014a). Strategic leadership of corporate sustainability. Journal of Business Ethics. Online publication ahead of print. doi:10.1007/s10551-013-2017-3.

Strand, R. (2014b). CSR and leadership. In E. R. G. Pedersen (ed.), Corporate Social Responsibility. SAGE, London, forthcoming.

Strand, R. (2014c). Scandinavia can be an inspiration for creating shared value. Financial Times Business Education Soapbox. http://www.ft.com/intl/cms/s/2/84bbd770-b34d-11e3-b09d-00144 feabdc0.html\#axzz2zw0bVEbR.

Thomsen, S., \& Conyon, M. (2012). Stakeholder Governance in Scandinavia. In Corporate Governance: Mechanisms and Systems, (pp. 285-305). McGraw Hill.

Transparency International Corruption Perceptions Index. (2013). http://cpi.transparency.org/cpi2013/results. Retrieved 1 May 2014.

Walsh, J. P. (2008). CEO compensation and the responsibilities of the business scholar to society. The Academy of Management Perspectives, 22(2), 26-33.

World Economic Forum. (2003). Global competitiveness report, 2003-2004. Davos, Switzerland: World Economic Forum.

World Economic Forum. (2013). Sustainability-adjusted global competitiveness index. http://www.weforum.org/content/pages/ sustainable-competitiveness. Retrieved 1 May 2014. 